\title{
PREVALENCE OF URINARY INCONTINENCE AND ITS ASSOCIATION WITH DECLINED COGNITIVE AND PHYSICAL FUNCTION AMONG COMMUNITY DWELLING OLDER ADULTS: A REVIEW
}

\author{
Resshaya Roobini Murukesu ${ }^{1}$, Devinder Kaur Ajit Singh ${ }^{1}$ and Suzana Shahar ${ }^{2}$ \\ ${ }^{1}$ Physiotherapy Programme, School of Rehabilitation Sciences, Faculty of Health Sciences, Universiti \\ Kebangsaan Malaysia, Malaysia \\ ${ }^{2}$ Community Rehabilitation and Aging Research Centre, Faculty of Health Sciences, Universiti Kebangsaan \\ Malaysia, Malaysia
}

Corresponding Author: Devinder Kaur Ajit Singh

Email: devinder@ukm.edu.my

\begin{abstract}
In this review we aimed to determine the prevalence of urinary incontinence (UI) and its association with declined cognitive and physical function among community dwelling older adults. Literature review was performed using multiple online databases including MEDLINE, Science Direct and Wiley Online Library from June 2000 to April 2017. Hand searching of bibliographies of relevant studies was also carried out. The studies included of those conducted from within the last 17 years; assessed and compared according to population characteristics, definition of urinary incontinence, prevalence and its association with cognitive and physical functional decline. Nine studies met the eligibility criteria of this review. Prevalence rates of UI among community dwelling older adults ranged from 10\% to 53\% (median 32\%). Physical functional decline in terms of mobility, locomotion and activities of daily living interruptions were found to be correlated with Ul. Although limited, the existing evidence also showed an association between declined cognitive function and $\mathrm{UI}$.
\end{abstract}

Keywords: community dwelling; older adults; geriatrics; urinary incontinence; cognitive function; physical function; risk factors.

\section{INTRODUCTION}

Urinary incontinence (UI) is lower urinary tract dysfunction defined by the International Continence Society (ICS) as an involuntary loss of urine resulting in social or hygienic problems ${ }^{1}$. UI has been characterized as a 'cardinal geriatric syndrome' affecting at least $19 \%$ and $10 \%$ older women and men respectively ${ }^{2,3,4}$. The prevalence of $\mathrm{UI}$ increases with age $^{5}$. Although, found to be more prevalent in women, it reaches a point of equivalence above the age of 80 in both genders ${ }^{6,7,8}$.

UI among older adults is often unaddressed due to the misconception that it is a part of natural ageing process. UI is associated with institutionalisation among older adults. This is due to its debilitating nature which results in increased socioeconomic and health burden; depression and frailty in older adults ${ }^{9,10}$. UI is associated with cognitive and physical impairments in frail institutionalised older adults with dementia9,11.
The presence of cognitive and physical impairments, collectively termed as 'functional incompetence' appear to be common among older adults dealing with $\mathrm{UI}^{12}$. The importance of these functional domains in the aim of maintaining continence has been established in the "Chain of Continence'13. High motivation and good mental status is vital in providing inhibition to void, followed by sufficient mobility to use the toileting facility independently in time.

There is an evident underrepresentation of community dwelling older adult population in addressing the association of UI with declined cognitive and physical function. Current knowledge of the prevalence of $\mathrm{UI}$ among community dwelling older adults is essential for prevention and management strategies, prolong independent living and reducing likelihood of institutionalisation. Hence, in this review we aimed to address two research questions: What is the 1) current known prevalence of $\mathrm{UI}$ and 2) association between $\mathrm{UI}$ and declined cognitive and physical function among community dwelling older adults? 


\section{METHODS}

\section{Search Strategy}

Studies published in English language from June 2000 to April 2017 were included based on the eligibility criterion via research databases; namely Wiley Online Library, MEDLINE (through PubMed), The Cochrane Library, Google Scholar and Science Direct using MeSH terms and keywords. General terms pertaining the title of study were keyed in, generating a large primary search to avoid missing related articles. Terms used were "prevalence", "urinary incontinence", paired with, "community dwelling", "older adults", "association", "cognitive impairment", and/or "physical impairment". Hand searching was additionally executed via reviewing the bibliographies of the retrieved articles for related articles. Inclusion criteria were: studies conducted among community dwelling older adults reporting the prevalence of $\mathrm{UI}$ and studies associating declined cognitive and/or physical impairments with Ul. Exclusion criteria were: studies involving subjects below age of 60 , institutionalised older adults and experimental studies involving management of Ul.

\section{RESULTS}

\section{Selection Process}

The flow chart in Figure 1 summarises the process of article selection in this review.

Sampling and Measurement

Included sample characteristics of the studies reviewed are as enlisted in Table I. Nine studies were reviewed and the sample size studies ranged from 223 to $23,447,726$, with a median of 2866 . The study with the largest populations was from the United States. The mean age of older adults, ranged from $69.7 \pm 6.8$ to $80.1 \pm 7.2$ years old.

Only two studies reported the response rate percentages at 77 and $84.8 \%^{14,15}$. Most studies reported the prevalence of both genders; however, three studies included only women $^{16,17,18}$ and one study included only men $^{19}$. Exclusion criterion in some studies included age $(<60,<65$, or $<75$ years $)$, gender and institutionalised older adults. Table II depicts the common significant risk factors found in previously conducted studies.

Measurement of UI was done subjectively using self-administered questionnaires. Only one study was found to use the validated International Consultation on Incontinence
Questionnaire-Short Form (ICIQ-SF) to measure $\mathrm{U}^{19}$. Studies with the assessment of cognitive and physical function in association with $\mathrm{UI}$ is as described in Table III.

\section{Prevalence of Urinary Incontinence}

The overall prevalence of UI among community dwelling older adults ranged from $10 \%$ to $53 \%$ with a median of $32 \%$. The summary of all reviewed studies can be found in Table 1 . The commonly used definition of $\mathrm{UI}$ in these studies, was found to implicate leakage of urine. Logically, a trend or pattern could not be observed based on the country, gender, sample size or mean age due to the wide range of results reported. The prevalence of $\mathrm{UI}$ for women ranged from $3 \%$ to $53 \%$ and $12 \%$ to $39 \%$ in men. All but one study reported a higher prevalence in women compared to men ${ }^{14}$.

A total of fifteen risk factors were investigated cumulatively in the reviewed studies. The association and significance of these risk factors with UI were determined using statistical tests; namely, chi square test, chi square for trend and multivariate logistic regression analysis. Table II is a summary of the six risk factors of $\mathrm{Ul}$ investigated and found to be significant in at least three studies.

Association between UI, declined cognitive and physical function

The characteristics of four studies which investigated declined cognitive and physical function as risk factors of $\mathrm{UI}$ for community dwelling older adults is summarised in Table III. The association between UI, declined cognitive and physical function were statistically analysed using logistic regression test and the results were reported with either P-value or odds ratio. Three studies distinguished between physical function and functional status as separate risk factors of UI; measuring both Activities of daily living (ADLs), and administering specific physical tests $^{8,9}$. However, functional status was clustered under physical function in this review, as execution of ADLs can be considered as physical tasks. 
Malaysian Journal of Public Health Medicine 2019, Vol. 19 (1): 31-40

Table 1: Sample Characteristics and Prevalence of Urinary Incontinence among Community Dwelling Older Adults.

\begin{tabular}{|c|c|c|c|c|c|c|c|c|}
\hline \multirow{3}{*}{ Reference } & \multirow{3}{*}{ Country } & \multicolumn{3}{|c|}{ Sample Characteristics } & \multirow{3}{*}{ Definition of UI } & \multicolumn{3}{|c|}{ Prevalence of UI } \\
\hline & & \multirow{2}{*}{$\begin{array}{l}\text { Respondents } \\
(n)\end{array}$} & \multirow[t]{2}{*}{ Mean Age } & \multirow[t]{2}{*}{ Male/Female/Both } & & \multirow{2}{*}{$\begin{array}{c}\text { Overall } \\
(\%)\end{array}$} & \multicolumn{2}{|c|}{ By Gender } \\
\hline & & & & & & & Male (\%) & $\begin{array}{c}\text { Female } \\
(\%)\end{array}$ \\
\hline Anger et al. (2006) & USA & $23,477,726$ & RA & Female & Difficulty controlling urine & 38 & - & 38 \\
\hline Anger et al. (2006) & USA & $18,231,934$ & RA & Male & Difficulty controlling urine & 17 & 17 & - \\
\hline $\begin{array}{l}\text { Du Moulin et al. } \\
(2008)\end{array}$ & Netherlands & 2866 & $80.1 \pm 7.2$ & Both & Involuntary leakage of urine & 46 & 39 & 51 \\
\hline Fritel et al. (2013) & France & 1942 & $79.3 \pm 2.9$ & Female & Involuntary leakage of urine & 43 & - & 43 \\
\hline Huang et al. (2007) & USA & 6361 & $76.7 \pm 4.7$ & Female & Involuntary leakage of urine & 53 & - & 53 \\
\hline Iglesias et al. (2000) & Spain & 827 & $77.7 \pm 8.1$ & Both & Involuntary leakage of urine & 36 & 29 & 42 \\
\hline Maggi et al. (2001) & Italy & 2398 & $75.2 \pm 7.1$ & Both & Any urinary incontinence & 18 & 12 & 22 \\
\hline Sidik (2010) & Malaysia & 223 & $69.7 \pm 6.8$ & Both & $\begin{array}{l}\text { Problems with bladder } \\
\text { control }\end{array}$ & 10 & 18 & 3 \\
\hline Stoddart et al. (2001) & UK & 1540 & RA & Both & Any urinary incontinence & 27 & 23 & 31 \\
\hline
\end{tabular}

RA: Only range of age reported, Ul: Urinary Incontinence

\begin{tabular}{|c|c|c|c|c|c|c|c|}
\hline Reference & Country & Gender & Age & $\begin{array}{l}\text { Cognitive } \\
\text { Function }\end{array}$ & $\begin{array}{l}\text { Physical } \\
\text { Function }\end{array}$ & $\begin{array}{c}\text { Functional } \\
\text { Status }\end{array}$ & $\begin{array}{c}\text { Fecal } \\
\text { Incontinence }\end{array}$ \\
\hline Du Moulin et al. (2009) & Netherlands & $p<0.001$ & $p<0.001$ & $p<0.01$ & $p<0.001$ & $p<0.001$ & $p<0.001$ \\
\hline Fritel et al. (2013) & France & - & NR & - & $p<0.001$ & - & - \\
\hline Huang et al. (2007) & USA & - & - & $\begin{array}{c}(O R=1.6,95 \% \\
C . I=1.1-2.2)\end{array}$ & $\begin{array}{c}(O R=1.3,95 \% \\
C . I=1.1-1.6)\end{array}$ & - & - \\
\hline Iglesias et al. (2000) & Spain & $p<0.001$ & $\mathrm{p}<0.01$ & - & - & - & - \\
\hline Maggi et al. (2001) & USA & NR & $\mathrm{p}<0.01$ & - & $p<0.001$ & $\mathrm{p}<0.01$ & - \\
\hline Sidik (2010) & Malaysia & $p<0.05$ & $p<0.05$ & NR & - & $p<0.05$ & - \\
\hline
\end{tabular}

NR: p-value not reported. , OR: Odds ratio. , ( - ): Not assessed in study. 
Table 3a: Characteristics of Studies Reporting the Association between Cognitive Decline, Physical Function Decline and UI

\begin{tabular}{|c|c|c|c|c|c|c|c|}
\hline \multirow[b]{2}{*}{ Author(s) } & \multirow[b]{2}{*}{ Objective } & \multirow[b]{2}{*}{ Study Design } & \multirow[b]{2}{*}{$\begin{array}{l}\text { Inclusion } \\
\text { Criteria }\end{array}$} & \multicolumn{3}{|c|}{ Instrumentation } & \multirow[b]{2}{*}{ Main Findings } \\
\hline & & & & $\mathrm{UI}$ & $\begin{array}{l}\text { Cognitive } \\
\text { Function } \\
\end{array}$ & $\begin{array}{l}\text { Physical } \\
\text { Function }\end{array}$ & \\
\hline $\begin{array}{l}\text { Du Moulin et al. } \\
\text { (2008) }\end{array}$ & $\begin{array}{l}\text { To measure } \\
\text { prevalence of UI } \\
\text { in community } \\
\text { dwelling older } \\
\text { adults aged } 65 \\
\text { years old } \\
\text { receiving home } \\
\text { care services. }\end{array}$ & $\begin{array}{l}\text { Cross- } \\
\text { sectional } \\
\text { study }\end{array}$ & $\begin{array}{l}\text { Living at } \\
\text { home; } \\
\text { Receiving } \\
\text { home care; } \\
\text { Aged } 65 \text { and } \\
\text { above. }\end{array}$ & $\begin{array}{l}\text { Standardised } \\
\text { Questionnaire. }\end{array}$ & $\begin{array}{l}\text { Dementia } \\
\text { screened via } \\
\text { standardized } \\
\text { questionnaire, } \\
\text { not specified. }\end{array}$ & $\begin{array}{l}\text { 4-Point Response } \\
\text { Scale } \\
\text { 1=bed bound; } \\
\text { 2=chair bound; } \\
\text { 3=walking aids } \\
\text { used; } \\
\text { 4=ambulatory. } \\
\text { *Questionnaire } \\
\text { included } \\
\text { questions } \\
\text { pertaining ADL. }\end{array}$ & $\begin{array}{l}\text { Dementia }(P=0.014) \text {, } \\
\text { poor mobility and ADL } \\
\text { impairments }(P<0.001) \\
\text { were associated with UI } \\
\text { and older adults } \\
\text { experiencing these have } \\
\text { more reason for } \\
\text { admission to home care } \\
\text { services. }\end{array}$ \\
\hline $\begin{array}{l}\text { Fritel et al. } \\
(2013)\end{array}$ & $\begin{array}{l}\text { To assess the } \\
\text { association } \\
\text { between } \\
\text { functional } \\
\text { limitations } \\
\text { related to } \\
\text { mobility and } \\
\text { urinary } \\
\text { incontinence in } \\
\text { elderly women. }\end{array}$ & $\begin{array}{l}\text { Cross- } \\
\text { sectional } \\
\text { study }\end{array}$ & $\begin{array}{l}\text { Women; } \\
\text { Aged } 75 \text { to } \\
85 \text { years; } \\
\text { Living near } \\
\text { study venue; } \\
\text { Community } \\
\text { dwelling. }\end{array}$ & $\begin{array}{l}\text { i. ICIQ-SF } \\
\text { ii. Short from } \\
\text { (SF-36) quality } \\
\text { of life } \\
\text { questionnaire }\end{array}$ & - & $\begin{array}{l}\text { Mobility Test } \\
\text { i. Timed Up and } \\
\text { Go. } \\
\text { ii. 6-meter walk. } \\
\text { iii. Sit to stand. } \\
\text { Balance Test } \\
\text { i. Standing } \\
\text { balance. } \\
\text { ii. Walking } \\
\text { balance. } \\
\text { iii. Unipedal } \\
\text { Stance. }\end{array}$ & $\begin{array}{l}\text { Multivariate analysis of } \\
\text { the mobility tests } \\
\text { showed strong } \\
\text { association of } 6 \text { meter } \\
\text { walk test and balance } \\
\text { tests with urge Ul. Strong } \\
\text { relationship exists } \\
\text { between motor } \\
\text { functional problems and } \\
\text { Ul. } \\
\text { Decline in physical } \\
\text { functionality is } \\
\text { proportionate to severity } \\
\text { of Ul. }\end{array}$ \\
\hline
\end{tabular}


Table 3b: Characteristics of Studies Reporting the Association between Cognitive Decline, Physical Function Decline and UI

\begin{tabular}{|c|c|c|c|c|c|c|c|}
\hline \multirow{2}{*}{ Reference } & \multirow{2}{*}{ Objective } & & \multirow[b]{2}{*}{$\begin{array}{l}\text { Inclusion } \\
\text { Criteria }\end{array}$} & \multicolumn{3}{|c|}{ Instrumentation } & \multirow{2}{*}{ Main Findings } \\
\hline & & & & UI & $\begin{array}{l}\text { Cognitive } \\
\text { Function }\end{array}$ & $\begin{array}{l}\text { Physical } \\
\text { Function }\end{array}$ & \\
\hline $\begin{array}{l}\text { Huang et al. } \\
(2007)\end{array}$ & $\begin{array}{l}\text { To examine the } \\
\text { association } \\
\text { between } \\
\text { cognitive } \\
\text { decline, physical } \\
\text { function decline, } \\
\text { and urinary } \\
\text { incontinence in } \\
\text { older } \\
\text { community- } \\
\text { dwelling women }\end{array}$ & $\begin{array}{l}\text { Observational } \\
\text { study }\end{array}$ & $\begin{array}{l}\text { Community } \\
\text { dwelling; } \\
\text { Female; } \\
\text { Aged } 65 \text { and } \\
\text { older. }\end{array}$ & $\begin{array}{l}\text { Self- } \\
\text { administered } \\
\text { questionnaire. }\end{array}$ & $\begin{array}{l}\text { i. Modified } \\
\text { Mini Mental } \\
\text { State } \\
\text { Examination } \\
\text { (MMSE). } \\
\text { ii. Trails B } \\
\text { Test. } \\
\text { iii. Digit } \\
\text { Symbol } \\
\text { Substitution } \\
\text { Test. }\end{array}$ & $\begin{array}{l}\text { i. } 6 \text {-meter walk } \\
\text { test. } \\
\text { ii. } 5 \text { Chair } \\
\text { Stands. }\end{array}$ & $\begin{array}{l}\text { Women with physical } \\
\text { decline were more likely } \\
\text { to report weekly } \\
\text { incontinence. Women } \\
\text { with cognitive decline } \\
\text { were more likely to } \\
\text { report that incontinence } \\
\text { interfered with } \\
\text { activities. } \\
\text { Physical decline has been } \\
\text { found to have a higher } \\
\text { correlation with Ul } \\
\text { (p<0.001) as compared } \\
\text { to cognitive decline } \\
(p=0.002) \text {. }\end{array}$ \\
\hline $\begin{array}{l}\text { Maggi et al. } \\
(2001)\end{array}$ & $\begin{array}{l}\text { To estimate the } \\
\text { prevalence of UI } \\
\text { in a community } \\
\text { dwelling } \\
\text { population of } \\
\text { elderly Italians } \\
\text { and to determine } \\
\text { the associated } \\
\text { physical, social } \\
\text { and psychological } \\
\text { factors. }\end{array}$ & $\begin{array}{l}\text { Cross- } \\
\text { sectional } \\
\text { study }\end{array}$ & $\begin{array}{l}\text { Community } \\
\text { dwelling; } 65 \\
\text { years and } \\
\text { older. }\end{array}$ & $\begin{array}{l}\text { Standardised } \\
\text { questionnaire. }\end{array}$ & - & $\begin{array}{l}\text { Self-reported: } \\
\text { Mobility } \\
\text { Disability } \\
\text { i. Stair climbing. } \\
\text { ii. 800m walk. } \\
\text { ADLs Disability } \\
\text { i. Bathing } \\
\text { ii. Dressing } \\
\text { iii. Getting out } \\
\text { of bed. } \\
\text { iv. Eating. }\end{array}$ & $\begin{array}{l}\text { ADL disability and } \\
\text { mobility disability were } \\
\text { significantly associated } \\
\text { with UI in both older } \\
\text { men and women. } \\
\text { UI negatively impacts the } \\
\text { elderly's quality of life } \\
\text { and general health } \\
\text { status. }\end{array}$ \\
\hline
\end{tabular}


Total articles identified from search through

available online database $(n=234)$

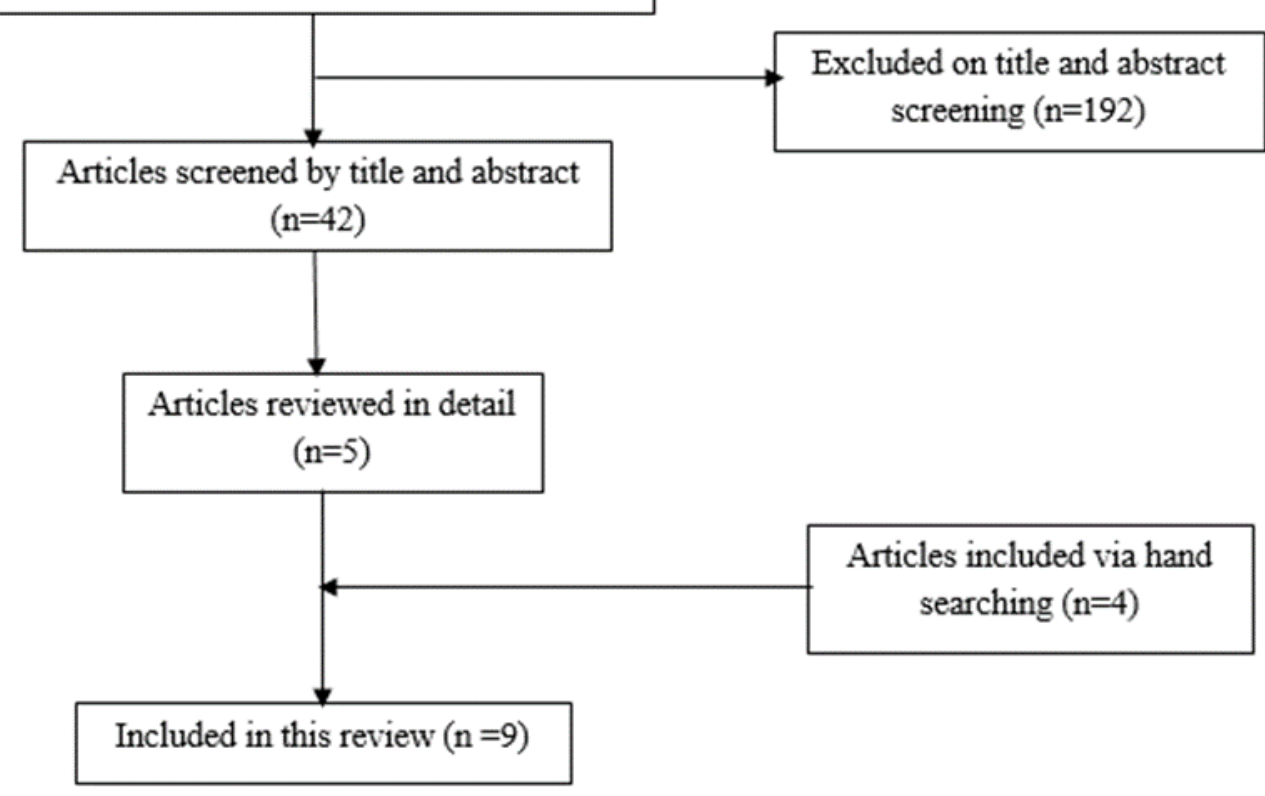

Figure I: Flow chart of article selection process.

\section{DISCUSSION}

We aimed to determine the prevalence of UI and investigate the association between $\mathrm{UI}$, declined cognitive and physical function among community dwelling older adults. UI was found to be a prevalent condition among community dwelling older adult population. An older adult with existing decline in cognitive and/or physical function was more likely to experience UI.

The prevalence of $\mathrm{UI}$ among community dwelling older adults ranged from $10 \%$ to $53 \%$, which is lower compared with the prevalence rates among the institutionalised (43\% to $77 \%$ ). The lowest prevalence of $\mathrm{UI}$ was reported at $10 \%$, set in Asia ${ }^{14}$. This may be influenced by the fact that participants in Asia are more ethnically conservative regarding delicate personal health concerns which are perceived to be sensitive ${ }^{14}$. This Asian study was the only study to report a contrast in the prevalence of $\mathrm{UI}$ whereby it was found to be higher among men compared to women ${ }^{14}$. These results may suggest underreporting of $\mathrm{UI}$ as information was obtained subjectively via interview.

The wide range in $\mathrm{Ul}$ prevalence between studies could stem from the differences in research methodology. A trend could be identified among studies based on the $\mathrm{UI}$ definition used. A higher prevalence rate $(36 \%$ to $53 \%$ ) was observed in studies that defined UI as "involuntary leakage of urine" 17,18,19. It was observed that prevalence rates were highest in studies where the lowest amount of urine leakage satisfied the definition. In three studies "difficulty controlling urine" and "problems with bladder control" was used $^{14,16,19}$. These definitions could have implied an absence of involuntary urine leakage. It could also be understood as a difficulty in restraining before reaching a toileting facility when the individual may not be experiencing incontinence per say. These ambiguous definitions used in investigating prevalence of $\mathrm{UI}$ may render its results less reliable, as it can be perceived and interpreted differently.

Though many validated and well-established $\mathrm{UI}$ assessment questionnaires exist, there is currently no gold standard subjective UI assessment instrument. In all the studies that we reviewed, information regarding UI was subjectively acquired. The self-administered questionnaires used to measure $\mathrm{UI}$ in each study were selected or created based on the definition of UI. Validity and reliability of 
questionnaires to assess $\mathrm{UI}$, its method of administration (face to face interview or via postal interview), participants' understanding of the questions asked, sensitivity of questions and the depth of content in the interview could also be related to the wide difference in reported prevalence ${ }^{20}$.

Generally, prevalence of $\mathrm{UI}$ is found to increase as the population ages. Mean age of incontinent older adults was higher compared to those who were continent ${ }^{21,22}$. However, it is not to be misconstrued as a natural consequence of ageing. It is more often a manifestation of other pre-existing age related medical conditions; commonly, diabetes mellitus, neurological disorders such as stroke or cerebrovascular accidents (CVA) and prostatic hyperplasia among men ${ }^{8,23}$. Wetle et al. stated that this phenomenon of increasing prevalence with age, is explained by the correlates of aging, rather than just age as a single factor ${ }^{22}$.

Prevalence of incontinence by age group was found to be higher among women than in men within 80 to 90 years; but reached a point of equivalence after 90 years. The increase of prevalence with age is described by Iglesias et al. as approximately 5\% per 5-year interval which implies an approximate increase of $1 \%$ annually ${ }^{24}$. Gender has also shown to be a significant risk factor of $\mathrm{UI}$ in this review, being more prevalent among women than men. Both gender and age as risk factors can be explained with changes in the anatomy and physiology of urological system such as involuntary bladder contractions, prostatic enlargement with detrusor instability or overflow incontinence in men; and postpartum changes, atrophic vaginitis or declining oestrogen levels in women ${ }^{20,25}$.

Several other risk factors of $\mathrm{UI}$ were reported. Anger et al. found ethnicity to be a risk factor with $\mathrm{UI}$ being more prevalent among older black men and white women ${ }^{16,19}$. The results also demonstrated an association between socioeconomic status and the likelihood of experiencing $\mathrm{UI}$, especially in population with lower income and without high school education ${ }^{16}$. Only one study showed an association between higher body mass index (BMI) and higher prevalence of $\mathrm{UI}^{23}$. Higher BMI is linked to higher intra-abdominal and intravesical pressure leading to UI due to stress applied on the pelvic floor ${ }^{26}$. Diabetes mellitus was associated with $\mathrm{UI}$ in two studies. Diabetes mellitus was found to be associated by 2.5 -fold as a risk factor of UI; possibly due to the risk of metabolic disturbances, neurological and/or vascular pathology ${ }^{27}$. Moreover, UI had a negative impact on quality of life among older adults with UI. UI poses a negative psychosocial impact on older adults resulting in social limitations and interference with executing daily tasks ${ }^{15,18,24}$.

Declined cognitive function was found to be significantly associated with $\mathrm{UI}$ in three studies in our review. In contrary, an association between cognitive status and $\mathrm{UI}$ was not established in an earlier study but depression was significantly associated with $\mathrm{UI}^{22}$. Though depression is not a cognitive impairment, it is a known related risk factor of cognitive decline ${ }^{28}$. Depression should be considered when screening older adults as it could be an indicator of cognitive decline ${ }^{28,29}$. In addition, UI was four times more prevalent among older adults with dementia as compared to those without cognitive impairments ${ }^{13}$. However, information about the association between $\mathrm{UI}$ and mild cognitive impairments $(\mathrm{MCl})$ is limited. Such information is important in view of potentially reversing $\mathrm{UI}$ by addressing the risk factors early.

Physical performance has been found to decline with age, parallel to the deterioration of other physiological components required to maintain optimum function ${ }^{30}$. Most studies in this review supported the importance of being independent in mobility and $\mathrm{ADL}$ as a core function of maintaining continence. Continent community dwelling older adults that are institutionalised have been found to become incontinent within a span of one year'. This illuminated the importance of maintaining physical mobility as a prevention of UI. Institutionalisation generally leads to high dependence on the caregivers to carry out basic ADLs, including toileting needs.

The results of our review showed that physical decline was a stronger predictor as compared to impaired cognition. It was concluded that women with declined physical function were more likely to deal with weekly incontinence ${ }^{18}$. Similarly, it was highlighted that impaired mobility and physical barriers had stronger association with $\mathrm{UI}^{4}$. This is further supported by an earlier study, reporting older adults with $\mathrm{UI}$ had functional impairment and were dependent in $A D L^{2}$.

One of the limitations of this review is that it only provides a descriptive summary of $\mathrm{UI}$ prevalence and its association with declined physical and cognitive function among 
community dwelling older adults, rather than a statistical meta-analysis. Also, in all studies $\mathrm{UI}$ and its related symptoms were assessed subjectively via questionnaires. These studies could be subjected to under or inaccurate reporting and response bias. However, objective testing of $\mathrm{Ul}$ requires appropriate clinical setting and does not guarantee the presentation of symptoms at time of testing, which renders it unfeasible in large community based studies. A lack of comparison between risk factors and its association with continent and incontinent community dwelling older adults should be noted as well.

As a recommendation for future research, UI definition should be standardised using the International Continence Society's one. This would enable easier study comparisons, understanding and inference. Secondly, valid and reliable questionnaires should be adapted in regard to instrumentation for $\mathrm{UI}$ assessment. Lastly, both genders should be included when investigating risk factors of $\mathrm{UI}$ as an aide for seamless healthcare practice.

\section{CONCLUSION}

Our review results highlights $\mathrm{UI}$ as a prevalent condition among both community dwelling older women and men. We also found declined physical function as a common determinant of Ul. Although limited, the existing evidence highlights that declined cognitive function is related to $\mathrm{UI}$. Routine screening of $\mathrm{UI}$ and identification of its associated risk factors among community dwelling older adults, especially cognitive and physical function, should be considered in health care practices to provide early and holistic management.

\section{ACKNOWLEDGMENTS}

This study is funded using a grant from Ministry of Higher Education Malaysia via Universiti Kebangsaan Malaysia (LRGS/BU/2012/UKM-UKM/K/01). We are also grateful to Mr Indarpal Singh Didar Singh for English editing and proof reading this paper.

Conflicts of interest: There is no conflict of interest.

\section{REFERENCES}

1. Abrams P, Anderson KE, Birder L. et al. $4^{\text {th }} \quad$ International Consultation Reccomendations of the International Scientific Committee: The Major Evaluation and Treatment of Urinary
Incontinence, Pelvic Organ Prolapse and Faecal Incontinence. Evauation and Treatment of Urinary Incontinence, Pelvic Organ Prolapse and Faecal Incontinence 2009; 1767820.

2. Holroyd-Leduc JM, Mehta KM, Covinsky KE. Urinary Incontinence and Its Association with Death, Nursing Home Admission, and Functional Decline. Journal of the American Geriatrics Society 2004; 51: 712-8.

3. Irwin DE, Milsom I, Hunskaar S. et al. Population-Based Survey of Urinary Incontinence, Overactive Bladder, and Other Lower Urinary Tract Symptoms in Five Countries: Results of the EPIC Study. European Urology 2006; 50(6): 1306-15.

4. Loh KY, Sivalingam N. Urinary Incontinence in the Elderly Population. The Medical Journal of Malaysia 2006; 61(4): 506-10.

5. Eshkoor SA, Hamid TA, Shahar S. et al. Factors related to urinary incontinence among the Malaysian elderl. Journal of Nutritional Health Aging 2017; 21(2): 220-26. doi: $10.1007 / \mathrm{s} 12603-016-0779-\mathrm{x}$.

6. Ho CCK, Teo CY, Phang LF, Azizi NAN, Darwin FL, Mohd Ghazi NA, Tan GH, Goh EH, Singam P, Bahadzor B, Zainuddin ZM. Prevalence and Risk Factors Associated with Overactive Bladder. Urotoday International Journal. 2012; 5(1): 88.

7. Kuchel GA, Dubeau CE. Chapter 30 : Urinary Incontinence in the Elderly. American Society of Nephrology 2009; 1-5.

8. Maggi S, Minicuci N, Langlois J. et al. Prevalence rate of urinary incontinence in community-dwelling elderly individuals: The Veneto Study. The Journals of Gerontology 2001; 56(1):14-8.

9. Offermans M, Du Moulin M, Hamers J, Dassen T. et al. Prevalence of Urinary Incontinence and Associated Risk Factors in Nursing Home Residents: A Systematic Review. Neurourology and Urodynamics 2009; 28(3):288-94. 
10. Yasmin S, Karim AJ, Rohaini M. et al. Prevalence of Urinary Incontinence and Associated Risk Factors in Postmenopausal Women. Medical Science 2013; 3(7): 66-70.

11. Williams M, Gaylord S. Role of Functional Assesment in the Evaluation of Urinary Incontinence. American Geriatrics Society 1990; 38(8): 296-9.

12. Bhagwath G. Urinary Incontinence in the Elderly: Pathogenesis and Management. Indian Academy of Clinical Medicine 2001; 2(4):270-5

13. Han D, Wang Y. Urinary incontinence in Dementia. Incontinence Pelvic Floor Dysfuntion 2008; 2(2):63-6.

14. Sidik SM. The prevalence of urinary incontinence among the elderly in a rural community in Selangor. Malaysian Journal of Medical Sciences 2010; 17(2): 18-23.

15. Stoddart H, Donovan J, Whitley E. et al. Urinary incontinence in older people in the community: A neglected problem? British Journal of General Practice 2001; 51(468): 548-52.

16. Anger JT, Saigal CS, Litwin MS. The Prevalence of Urinary Incontinence Among Community Dwelling Adult Women: Results From the National Health and Nutrition Examination Survey. The Journal of Urology 2006; 175: $601-4$

17. Fritel X, Lachal L, Cassou B. et al. Mobility impairment is associated with urge but not stress urinary incontinence in community-dwelling older women: Results from the Ossebo study. BJOG 2013; 120(12): 1566-72.

18. Huang J, Brown JS, Thom DH. et al. Urinary incontinence in older community-dwelling women: the role of cognitive and physical function decline. Obstetrics \& Gynecology 2007; 109(4): 909-16.

19. Du Moulin MF, Hamers JPH. et al. Prevalence of urinary incontinence among community-dwelling adults receiving home care. Research in
Nursing \& Health 2008; 31(6): 604-12.

20. Roberts R, Jacobsen S, Rhodes T. et al. Urinary Incontinence in a CommunityBased Cohort: Prevalence and Healthcare-Seeking. American Geriatric Society 1998; 46:467-72.

21. Nakanish N, Tatara K, Naramura H. et al. Urinary and fecal incontinence in a community-residing older population in Japan. Journal of the American Geriatrics Society 1997; 45(2):215-9.

22. Wetle T, Scherr P, Branch LG. et al. Difficulty with holding urine among older persons in a geographically defined community: prevalence and correlates. Journal of the American Geriatrics Society 1995; 43(4): 34955.

23. Anger JT, Saigal CS, Stothers L. et al. The prevalence of urinary incontinence among community dwelling men: results from the National Health and Nutrition Examination survey. The Journal of Urology 2006; 175: 2103-8.

24. Iglesias G, Pérez J, Valderrama E. et al. Prevalence and Psychosocial Impact of Urinary Incontinence in Older People of a Spanish Rural Population. The Journals of Gerontology 2000; 55(4): 207-14.

25. Dariah MY, Lily X, Belan I. et al. Postnatal Urinary Incontinence: Prevalence and Factors Associated with it in a Malaysian Population. Med \& Health 2014; 9(1):22-32.

26. Noblett KL, Jensen JK, Ostergard DR. The relationship of body mass index to intra-abdominal pressure as measured by multichannel cystometry. International Urogynecology Journal and Pelvic Floor Dysfunction 1997; 8(6):323-6.

27. Izci Y, Topsever P, Filiz TM. et al. The association between diabetes mellitus and urinary incontinence in adult women. International Urogynecology Journal and Pelvic Floor Dysfunction 2009; 20:947-952. 
28. Jorm AF. Is depression a risk factor for dementia or cognitive decline? Gerontology 2000; 46(4): 219-27.

29. Foong HF, Hamind TA, Ibrahim R. et al. Predicting cognitive function of the Malaysian elderly: a structural equation modelling approach. Aging and Mental Health 2016; 22(1):109120.
30. Singh DKA, Pillai SGK, Tan ST. et al. Association between physiological falls risk and physical performance test among community dwelling older adults. Clinical Interventions in Aging 2015; 10: 1319-26. 